\title{
LONGITUDINAL AND SEASONAL CHANGES IN FUNCTIONAL ORGANIZATION OF MACROINVERTEBRATE COMMUNITIES IN FOUR OREGON STREAMS ${ }^{1}$
}

\author{
Charles P. Hawkins \\ Department of Entomology, Oregon State University, \\ Corvallis, Oregon 97331 USA
}

AND

JAMEs R. SEDEll

United States Forest Service, Pacific Northwest Forest and Range Experiment Station, Forestry Sciences Laboratory, Corvallis, Oregon 97331 USA

\begin{abstract}
Relative numerical dominance and densities of invertebrate functional feeding groups are compared with longitudinal and seasonal changes in food resources in a Cascade Range stream system in Oregon. We also compare our data with hypothetical predictions of the River Continuum model.

We found that both relative abundances and densities of functional groups fit qualitative characterization of stream reaches and the River Continuum model: Shredders dominated upper shaded reaches; scrapers were most important in intermediate-sized sections; collectors increased in importance progressively downstream; predators were nearly constant in relative abundance at all sections; other functional groups were either rare or only locally abundant. Seasonal shifts also occurred but were not as dramatic as longitudinal differences.

Correlation analyses between quantitative measures of food sources and functional group abundance were usually significant. Lack of significance for some correlations is likely due to inaccurate characterization of food availability, but small sample size and improper classification of species' feeding behavior also may be important. In addition, invertebrate densities and food standing crop are static parameters and only approximately reflect the dynamics of consumer production and food availability.
\end{abstract}

Key words: community organization; distribution; functional feeding groups; macroinvertebrates; River Continuum; streams; trophic ecology.

\section{INTRODUCTION}

Shifts in community composition of stream invertebrates along longitudinal and seasonal gradients are well documented (see review by Hynes 1970). However, these studies have usually been analyses of taxonomic changes and provide little information on macroinvertebrate trophic organization within stream systems. A proper understanding of naturally occuring differences in stream community composition requires that we investigate how food availability regulates community organization.

Recently Vannote et al. (1980) and Cummins (1975) developed generalizations regarding invertebrate community organization in stream ecosystems from observations of physical and trophic phenomena that occur along longitudinal gradients. Their River Continuum hypothesis suggests stream morphology, current velocity, substrate composition, temperature, and allochthonous and autochthonous energy inputs interact to influence availability of food to invertebrate consumers. Furthermore, these interactions should vary systematically from headwater streams to larger rivers

\footnotetext{
${ }^{1}$ Manuscript received 15 October 1979; revised 10 April 1980; accepted 21 May 1980.
}

and thereby regulate distribution patterns of invertebrate functional feeding groups.

In this paper we analyze longitudinal and seasonal shifts in functional group abundance with concurrent changes in food availability in four Oregon streams. Our primary objective is to compare observations of invertebrate functional group distributions in Cascade Range streams to the generalizations formulated by Vannote et al. (1980).

\section{Materials ANd Methods}

$$
\text { Study site }
$$

Four streams in the western Cascade Range of Oregon were selected for study. These range in size from first to seventh order (Strahler 1957) and provide a gradient from small stream to mid-sized river (Table 1). Devilsclub Creek (first order) and Mack Creek (third order) are located in an old-growth Douglas-fir forest within the H. J. Andrews Experimental Forest. Most of Lookout Creek (fifth order) is outside of the major old-growth stand but is relatively unperturbed along its lower reaches. The sampling site on the McKenzie River (seventh order) and drainages upstream also exist in relatively natural states. No large natural or artificial impoundments are located above 
TABLE 1. Physical characteristics of the study streams.

\begin{tabular}{lcccccc}
\hline \hline \multicolumn{1}{c}{ Site } & $\begin{array}{c}\text { Strahler } \\
\text { order }\end{array}$ & $\begin{array}{c}\text { Watershed } \\
\text { area }\left(\mathrm{km}^{2}\right)\end{array}$ & $\begin{array}{c}\text { Gradient } \\
(\%)\end{array}$ & $\begin{array}{c}\text { Width* } \\
(\mathrm{m})\end{array}$ & $\begin{array}{c}\text { Mean discharge } \\
\left(\mathrm{m}^{3 / \mathrm{s}}\right)\end{array}$ & $\begin{array}{c}\text { Elevation } \\
(\mathrm{m})\end{array}$ \\
\hline Devilsclub & 1 & 0.20 & 40 & 2.6 & $0.01 \dagger$ & 800 \\
Mack & 3 & 6.0 & 13 & 12.5 & $0.3 \dagger$ & 785 \\
Lookout & 5 & 60.5 & 3 & 24.0 & 4.7 & 68.8 \\
McKenzie & 7 & 1024.0 & 0.6 & 40.0 & 365 \\
\hline
\end{tabular}

* Bank-full.

$\dagger$ Extrapolated from watershed area.

any site. A more thorough description of the study area and each site is given by Naiman and Sedell (1979).

\section{Sampling and analysis}

Benthic sampling methods are described by Naiman and Sedell (1979), but a more thorough description of invertebrate sampling methodology is given here. Each site was sampled each season during 1976 for benthic detritus, material suspended in the water column, primary production, and macroinvertebrates.

A hand-operated bilge pump was used to vacuum benthic material from $0.11 \mathrm{~m}^{2}$ of stream bed. While one person (equipped with either snorkeling or SCUBA gear) manipulated a suction hose over the substrate within a square quadrat, a second person operated the hand pump and directed vacuumed water and benthic material into nets. Water and particles passing through the smallest net were retained in a $200-\mathrm{L}$ plastic garbage can. After the substrate was vacuumed clean, volume of water collected was measured and subsamples for particles not retained by the nets were taken. Ten such samples were collected from each site each season based on sampling stratified according to major habitats. For Devilsclub Creek we collected only three or four samples. During winter, however, a kick net was used to collect qualitative samples only of invertebrates. We found these samples too dissimilar to quantitative samples from other seasons, and therefore we have excluded those data from this analysis.

Vacuum sampling was chosen over other standard collecting techniques such as coring devices or surbertype samplers (see Merritt and Cummins 1978:21 for picture) because of the depth of water encountered at some sites. Water depths of up to $1.2 \mathrm{~m}$ prevented use of other techniques. Although we have no quantitative evaluation of the efficiency of this method compared with other methods, it was the only technique that we could use at all sites.

Abundance of food other than benthic detritus was estimated as follows. Primary production (net daily metabolism, NDM; gross primary production, GPP) of stream substrates was estimated by the closedchamber method (McIntire et al. 1964, Bott et al. 1978). Naiman and Sedell (1980a) discuss in detail methods used in estimating these parameters. Particles
$>100 \mu \mathrm{m}$ in transport were sampled with high-speed plankton nets (Naiman and Sedell 1980b). Particles < $100 \mu \mathrm{m}$ were sampled by sieving stream water through nested 100- and 50- $\mu \mathrm{m}$ nets and then filtering through $0.45-\mu \mathrm{m}$ glass fiber filters. Transport samples generally were taken at intervals over a $24-$ to 72 -h period.

Benthic and transport samples were separated in the field into eight size fractions ranging from $0.45 \mu \mathrm{m}$ to $16 \mathrm{~mm}$. For this analysis, size fractions are lumped into coarse particulate organic matter (CPOM, >1 $\mathrm{mm}$ ), fine particulate organics (FPOM, $.05 \mathrm{~mm}-1 \mathrm{~mm}$ ), and very fine particulate organics (VFPOM, $0.45 \mu \mathrm{m}-$ $.05 \mathrm{~mm})$. CPOM as reported here differs from that as discussed by Naiman and Sedell (1979) in that large branches and bole wood are excluded from CPOM quantity estimates. These substrates exhibit very slow decay rates, are of minimal nutritive value, and as such contribute insignificantly to food actually available to most consumers on a seasonal or annual basis (Anderson et al. 1978, Anderson and Sedell 1979).

In addition to estimates of detritus quantity, determination of food quality also was attempted. Respiration rates were estimated for both benthic detritus and transported material with a differential respirometer (Gilson 1963). Temperatures were adjusted to mean stream temperatures recorded during each sampling period. Chlorophyll $a$ (corrected for pheophytin) present in each size fraction was estimated by methods outlined by Strickland and Parsons (1972). Total carbon and nitrogen were determined with a Carbo Erba Elemental Analyzer.

Invertebrates were picked from all detritus fractions $>0.5 \mathrm{~mm}$. All invertebrates with the exception of the Chironomidae were identified to lowest possible taxonomic level and the number of individuals in each taxa from each sample counted and recorded. Because of difficulty in identifying and assigning functional roles to most Chironomidae, they are excluded from this analysis. All other taxa were assigned to a functional group based on tables in Merritt and Cummins (1978). Some taxa did not fit well into a single functional group and were treated either as composites of other groups or placed in groups not explicitly categorized by Merritt and Cummins (see Appendix). Groups used include collectors ("collector-gatherers"), scrapers, shredders, filter-feeders, ("filterers"), predators, woodgougers, and generalists. The Appendix 

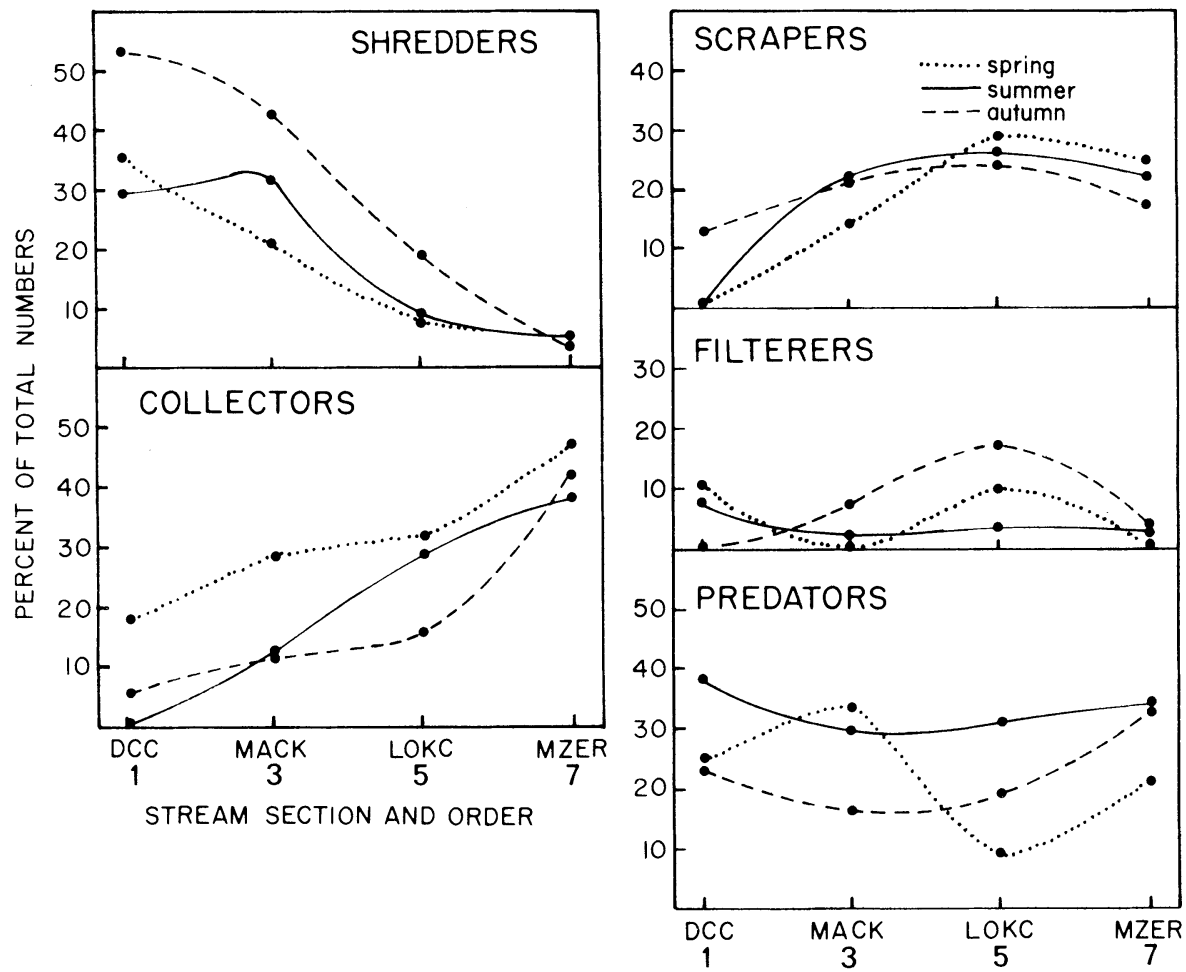

FIG. 1. Longitudinal shifts in relative abundance of different functional feeding groups for spring, summer, and autumn 1976. DCC $=$ Devilsclub Creek, MACK $=$ Mack Creek, LOKC $=$ Lookout Creek, MZER $=$ McKenzie River.

includes a list of all taxa encountered and their functional designation. ${ }^{2}$

From these data, estimates of density and relative abundance of each functional group were calculated for each stream. Relative abundances are calculated for spring, summer, and autumn. Densities were best estimated for summer and autumn and are compared with benthic primary production and quantities of CPOM, FPOM, and VFPOM collected for those seasons. A number of personnel sorted spring samples, whereas the first author processed all summer and autumn samples. Individual differences in efficiency of sorting spring samples were noted. Therefore, only summer and autumn densities are analyzed.

Percent of each habitat for each site and season was estimated, and samples taken from all major habitats. Mean densities of the different functional groups for each stream section were calculated based on this stratified design. Variance associated with mean densities was usually high (c.v. $=20-128)$ and indicated strongly aggregated distributions. Because we were mainly interested in general trends among sites and

${ }^{2}$ See National Auxiliary Publications Service document \#3770 for 5 pages of supplementary tables of taxa encountered and their densities for each site. For a copy of this document, contact the senior author or order from ASIS/ NAPS, Microfiche Publications, P.O. Box 3513, Grand Central Station, New York, New York 10017 USA. not specific differences between sites, we have not included estimates of variance for either food sources or invertebrates. These data are available in other publications (Naiman and Sedell 1979, 1980a and $b$ ) or from senior author.

\section{Results AND Discussion}

\section{Functional group ratios and densities}

The relative importance of each functional group to community organization was determined by examining dominance ratios (density of functional group/total invertebrate density) for each group. Shredders dominated low-order sections and gradually decreased in importance downstream (Fig. 1). Collectors, conversely, were relatively unimportant in upstream reaches but dominated higher order sites. Scrapers gradually increased in importance, reached maximum dominance in Lookout Creek, and then declined. Filter-feeders, although relatively unimportant in these streams, reached maximum dominance in Lookout Creek also. Predators exhibited rather constant dominance values between sites except for the spring season. Other functional groups (woodgougers and generalists) were a minor component at most sites.

Seasonal shifts in relative abundance of each group occurred to varying degrees at all sites (Fig. 1). Devilsclub Creek was always dominated by shredders and predators, although woodgougers were also im- 


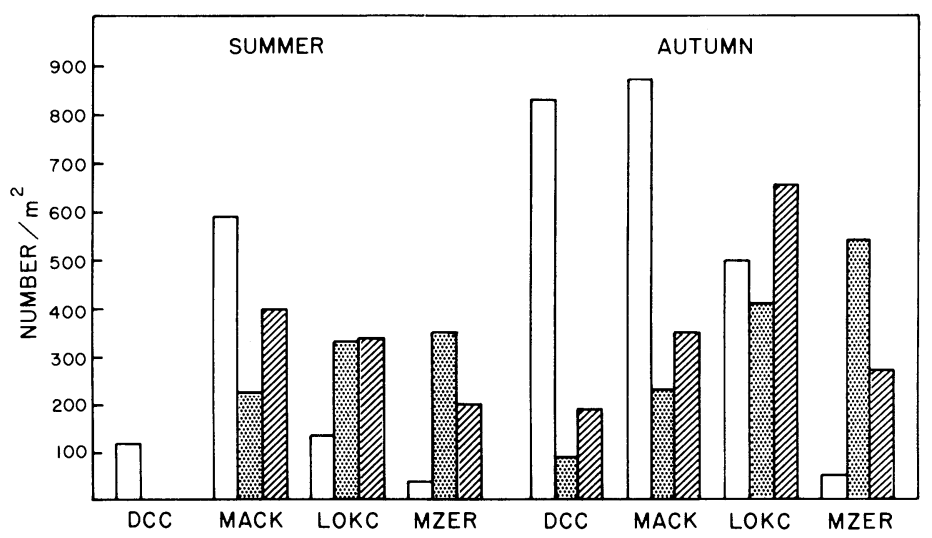

FIG. 2. Densities of shredders (white bars), collectors (stippled bars), and scrapers (hatched bars) observed at each site during summer and autumn. Stream sections abbreviated as in Fig. 1.

portant during the summer. In Mack Creek shredders increased in importance from spring to autumn, whereas collector and predator components decreased in relative abundance. Lookout Creek was generally dominated by collectors and scrapers, but increases in shredder densities in autumn (Fig. 2) at least partially accounted for a slight decrease in the relative abundance of collectors during this season. Collectors outnumbered all other herbivorous or detritivorous groups at the McKenzie River site and exhibited little seasonal variation.

Shifts in densities of shredders, collectors, and scrapers at each site show a pattern similar to that of changes in relative abundance along the longitudinal stream gradient (Fig. 2). Shredder densities were always greatest in upstream reaches, collectors were most abundant downstream, and scraper densities peaked in the two intermediate-sized stream sections.

In general, observations of both relative importance (ratios) and densities support the generalizations of the River Continuum model. They also conform well to the following subjective characterization of trophic environments occurring at each site. Headwater sites are surrounded by heavy riparian and coniferous forest canopies which imply large inputs of leaf, needle, and woody debris. In Mack Creek we observed distinct shredder dominance. Devilsclub Creek did not have comparable populations with Mack Creek, but this may be an effect of large accumulations of silt that are retained by many large rotting logs. Populations of most taxa and functional groups in this stream were depressed (Fig. 2). Large numbers observed in autumn are recently hatched early instars, which may have experienced very high mortality. Other first-order streams in the Andrews Forest have higher total populations and a shredder-dominated community (N. H. Anderson, personal communication). Lookout Creek is open to sunlight, and abundant algal and diatom populations were found there. Scrapers were generally most important here. The McKenzie River was more difficult to characterize by eye. However, bank perimeter to water surface ratios would strongly suggest minimal local terrestrial CPOM inputs per unit area of stream bed. Aquatic mosses (Fontinalis sp. and others) were much more abundant here than elsewhere. Because of the general unpalatability of moss and the relatively small leaf inputs, major food sources seem to originate upstream and be transported down. These observations imply that small loose particles (FPOM) are the major food source available here.

\section{Densities and food availability}

The River Continuum model of functional group distribution can be more meaningfully evaluated if, in addition to patterns of distribution, density-food relationships also are examined. If functional group classification of taxa encountered is accurate, abundance of food resources should be a reasonable predictor of functional group abundance. Poor associations would indicate either improper functional classification of taxa or inadequate resolution in characterization and/ or quantification of food availability (see discussion below).

We graphed densities of animals against their most likely food sources. Relationships examined include shredders vs. CPOM, collectors vs. FPOM and VFPOM, scrapers vs. net daily metabolism and chlorophyll on rocks, and predators vs. prey. Other functional groups were not abundant enough to allow meaningful analysis. Data generally were transformed to common logarithmic scales both to facilitate graphing and because vertical scatter (variance) between densities at high resource levels was usually greater than at low levels. Correlation coefficients $(r)$ were calculated from these data to assess degree of association.

Shredders.-Shredders were significantly correlated (summer $r=.55, P<.01, n=28$; autumn $r=.53$, $P<.05, n=34$ ) with CPOM levels (Fig. 3). Considerable unexplained variance is apparent, although this 


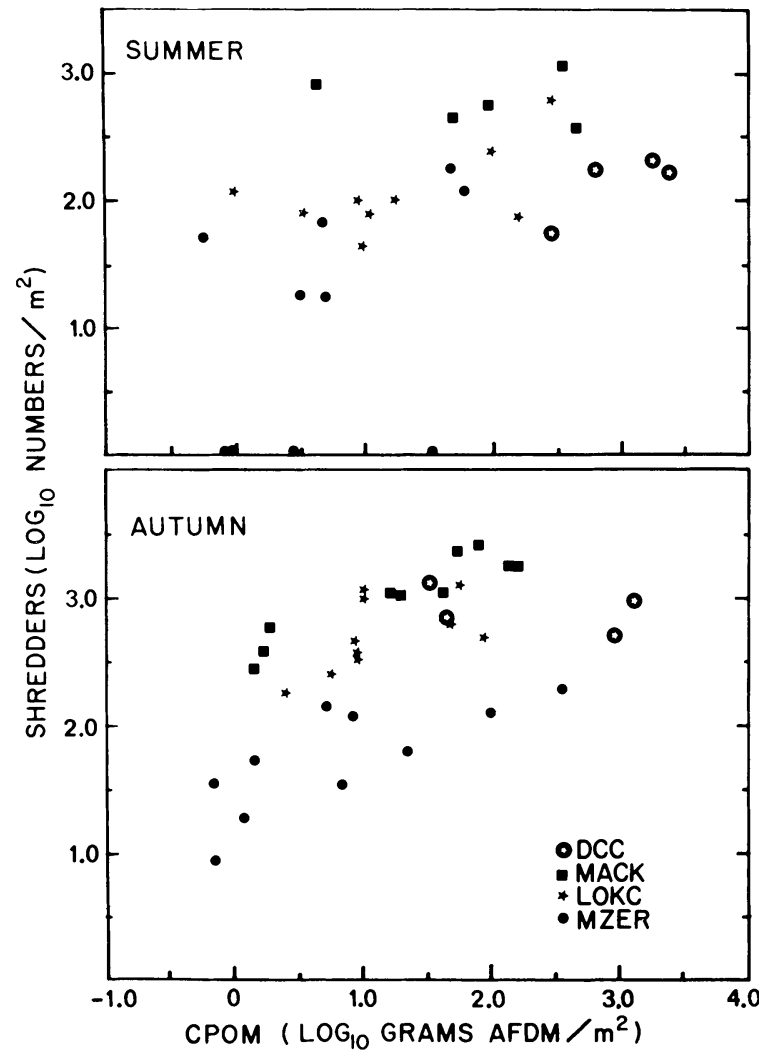

FIG. 3. Shredder densities in relation to CPOM levels. Correlation coefficients for all sample points: summer: $r=$ $.55, P<.01, n=28$; autumn: $r=.53, P<.05, n=34$. Correlation coefficients for each site separately: summer: Mack, $r=.20$, NS, $n=5$; Lookout, $r=.54$, NS, $n=9$; McKenzie, $r=.40$, NS, $n=10$; autumn: Mack, $r=.91$, $P<.01, n=10$; Lookout, $r=.58$, NS, $n=10$; McKenzie, $r=.64, P<.05, n=10$.

is partly due to site differences. Because CPOM measurement included both leaf material and small woody debris, obvious qualitative differences in CPOM both among samples within a site and among sites would be expected. Independently significant correlations within some sites between shredder numbers and CPOM quantity might therefore be partly due to qualitative differences in CPOM. Densities of shredders per gram CPOM are higher in Mack Creek, a shaded site, where leaf:wood ratios may be greater than in the McKenzie River. Differential retention or rapid processing of leaves upstream, and export and downstream accumulation of mostly woody CPOM, could account for these trends.

Recent studies have shown that CPOM food quality can be as important as food quantity in limiting population growth and abundance of shredders (Kaushik and Hynes 1971, Barlöcher and Kendrick 1973, MacKay and Kalff 1973, Iversen 1974, Anderson 1976, Anderson and Cummins 1979, Anderson and Sedell 1979). C: $\mathrm{N}$ ratios and respiration rates of CPOM (Ta- ble 2), however, exhibit no clear trend in CPOM quality between sites. The ambiguity of these data is likely due to our failure to estimate quantity and quality of each CPOM fraction independently (i.e., deciduous leaves, conifer needles, and wood) for our sites. Shredders are probably responding largely to leaf and needle inputs. Estimates of quantity and quality for conglomerate collections of CPOM could mask real differences in readily available food items. Animals classed as shredders are thought to feed preferentially on leaf material (Cummins 1973, 1974). Highest shredder densities were found during autumn, the period of greatest leaf fall, which further supports a shredderleaf association.

The significant correlations we did observe between shredder numbers and total CPOM levels imply that either qualitative differences in CPOM are not as important as previously thought or that high-quality CPOM is simply associated with other CPOM fractions.

Collectors.-Although collector abundance also corresponded to predictions of the River Continuum model, collector numbers did not correlate significantly with either FPOM or VFPOM quantity $(r=$ .30 , NS, $n=28 ; r=.21$, Ns, $n=34$, respectively). A possible explanation for lack of a significant animal/ detritus association is that FPOM and VFPOM are composed of heterogeneous types of organic particles that differ greatly in standing crop and nutritional value. Fecal material, flocculated organic aggregates, bacteria, algal and diatom cells, as well as fractionated CPOM, contribute to FPOM-VFPOM pools. If most FPOM or VFPOM is composed of refractory particles of low food value, relatively large differences in quantity may reflect only small differences in true food availability. Quality, in fact, is probably inversely related to quantity since high-quality food sources are consumed and assimilated, whereas low-quality particles, if consumed, are simply passed through the gut and returned to FPOM pools.

Previous studies suggest that a small fraction of natural detritus is selectively assimilated by consumers and that the rest is in fact passed rather quickly through the gut (Schindler 1968, Bell and Ward 1970, Hargrave 1970). Baker and Bradnam (1976) provide some evidence that bacteria are selectively stripped from food particles by Simulium and Chironomus. Davies (1975) proposed selective feeding on richer food sources by Trissocladius sp., a chironomid midge.

Only when we plotted mean collector numbers at each site against the amount of chlorophyll $a$ per gram of VFPOM did we obtain a significant correlation for this group (Fig. $4 ; r=.78, P<.05, n=8$ ). Other quality measures of FPOM and VFPOM did not vary as systematically as chlorophyll $a$ levels (Table 2) and were inadequate for predicting collector abundance in these streams. Therefore, in western Cascade stream 
TABLE 2. Quality measures of detritus size fractions for winter (March), spring (May), summer (July), and autumn (October) 1976. Respiration rate (Resp), chlorophyll a concentration (Chlor), percent nitrogen, and C: $N$ ratios are presented for Devilsclub Creek (DCC), Mack Creek (MACK), Lookout Creek (LOKC), and the McKenzie River (MZER).

\begin{tabular}{|c|c|c|c|c|c|c|c|c|c|}
\hline $\begin{array}{l}\text { Par- } \\
\text { ticle } \\
\text { size } \\
\text { class }\end{array}$ & Site & $\begin{array}{c}\text { Resp } \\
\left(\mu \mathrm{L} \mathrm{O}_{2} \cdot \mathrm{g}^{-1}\right. \\
\mathrm{AFDM}^{-1} \\
\left.\mathrm{~h}^{-1}\right)\end{array}$ & $\begin{array}{c}\text { Chlor } \\
(\mu \mathrm{g} \\
\text { chloro- } \\
\text { phyll } a / g \\
\text { AFDM })\end{array}$ & $\% \mathrm{~N}$ & $C: N$ & Resp & Chlor & $\% \mathrm{~N}$ & $\mathrm{C}: \mathrm{N}$ \\
\hline & & \multicolumn{4}{|c|}{ Winter } & \multicolumn{4}{|c|}{ Summer } \\
\hline СРОМ & $\begin{array}{l}\text { DCC } \\
\text { MACK } \\
\text { LOKC } \\
\text { MZER }\end{array}$ & $\begin{array}{r}8 \\
35 \\
25 \\
16\end{array}$ & $\begin{array}{l}* \\
* \\
* \\
*\end{array}$ & $\begin{array}{l}0.8 \\
2.7 \\
1.6 \\
1.2\end{array}$ & $\begin{array}{l}66 \\
28 \\
32 \\
38\end{array}$ & $\begin{array}{r}30 \\
35 \\
117 \\
21\end{array}$ & $\begin{array}{r}4 \\
19 \\
22 \\
37\end{array}$ & $\begin{array}{l}1.2 \\
1.0 \\
1.3 \\
1.0\end{array}$ & $\begin{array}{l}38 \\
58 \\
41 \\
41\end{array}$ \\
\hline FPOM & $\begin{array}{l}\text { DCC } \\
\text { MACK } \\
\text { LOKC } \\
\text { MZER }\end{array}$ & $\begin{array}{l}40 \\
31 \\
57 \\
33\end{array}$ & $\begin{array}{l}* \\
* \\
* \\
*\end{array}$ & $\begin{array}{l}1.0 \\
1.5 \\
0.5 \\
0.8\end{array}$ & $\begin{array}{l}29 \\
20 \\
12 \\
19\end{array}$ & $\begin{array}{r}43 \\
96 \\
109 \\
123\end{array}$ & $\begin{array}{r}3 \\
7 \\
13 \\
5\end{array}$ & $\begin{array}{l}1.2 \\
1.2 \\
0.6 \\
0.6\end{array}$ & $\begin{array}{l}25 \\
15 \\
15 \\
18\end{array}$ \\
\hline \multirow[t]{2}{*}{ VFPOM } & $\begin{array}{l}\text { DCC } \\
\text { MACK } \\
\text { LOKC } \\
\text { MZER }\end{array}$ & $\begin{array}{l}* \\
* \\
* \\
*\end{array}$ & $\begin{array}{l}* \\
* \\
* \\
*\end{array}$ & $\begin{array}{l}1.2 \\
1.4 \\
0.8 \\
0.8\end{array}$ & $\begin{array}{r}13 \\
13 \\
4 \\
9\end{array}$ & $\begin{array}{l}169 \\
187 \\
210 \\
417\end{array}$ & $\begin{array}{r}76 \\
117 \\
316 \\
444\end{array}$ & $\begin{array}{l}* \\
* \\
* \\
*\end{array}$ & $\begin{array}{l}* \\
* \\
* \\
*\end{array}$ \\
\hline & & \multicolumn{4}{|c|}{ Spring } & \multicolumn{4}{|c|}{ Autumn } \\
\hline СРОМ & $\begin{array}{l}\text { DCC } \\
\text { MACK } \\
\text { LOKC } \\
\text { MZER }\end{array}$ & $\begin{array}{l}14 \\
25 \\
28 \\
81\end{array}$ & $\begin{array}{r}0 \\
9 \\
17 \\
39\end{array}$ & $\begin{array}{l}1.0 \\
0.8 \\
1.6 \\
1.7\end{array}$ & $\begin{array}{l}76 \\
56 \\
40 \\
39\end{array}$ & $\begin{array}{l}94 \\
64 \\
42 \\
70\end{array}$ & $\begin{array}{r}2 \\
142 \\
14 \\
241\end{array}$ & $\begin{array}{l}0.9 \\
1.0 \\
1.3 \\
1.6\end{array}$ & $\begin{array}{l}62 \\
76 \\
36 \\
32\end{array}$ \\
\hline FPOM & $\begin{array}{l}\text { DCC } \\
\text { MACK } \\
\text { LOKC } \\
\text { MZER }\end{array}$ & $\begin{array}{l}18 \\
40 \\
71 \\
72\end{array}$ & $\begin{array}{r}0 \\
4 \\
116 \\
16\end{array}$ & $\begin{array}{l}0.7 \\
0.8 \\
1.3 \\
1.1\end{array}$ & $\begin{array}{l}25 \\
17 \\
14 \\
17\end{array}$ & $\begin{array}{l}30 \\
37 \\
57 \\
67\end{array}$ & $\begin{array}{r}1 \\
12 \\
31 \\
22\end{array}$ & $\begin{array}{l}0.6 \\
1.1 \\
0.8 \\
0.6\end{array}$ & $\begin{array}{l}32 \\
20 \\
16 \\
18\end{array}$ \\
\hline VFPOM & $\begin{array}{l}\text { DCC } \\
\text { MACK } \\
\text { LOKC } \\
\text { MZER }\end{array}$ & $\begin{array}{r}79 \\
241 \\
* \\
*\end{array}$ & $\begin{array}{r}0 \\
73 \\
* \\
132\end{array}$ & $\begin{array}{l}1.7 \\
1.1 \\
1.3 \\
*\end{array}$ & $\begin{array}{r}15 \\
18 \\
6 \\
*\end{array}$ & $\begin{array}{l}71 \\
70 \\
53 \\
78\end{array}$ & $\begin{array}{r}0 \\
12 \\
229 \\
394\end{array}$ & $\begin{array}{l}* \\
* \\
* \\
*\end{array}$ & $\begin{array}{l}* \\
* \\
* \\
*\end{array}$ \\
\hline
\end{tabular}

* Missing data.

systems, diatoms and other algal-derived food sources seem important in determining collector abundance.

Scrapers.-Scraper abundance was significantly correlated with standing crop of chlorophyll $a$ on cobbles ( $r=.76, P<.05, n=8$ ) (Fig. 5), but not with either gross community production $(r=.36$, NS) or net daily metabolism $(r=.26$, NS). These data are somewhat puzzling in that we originally believed that a dynamic variable describing production would predict consumer abundance more accurately than a static variable such as standing crop.

A number of factors are known that can obscure scraper/periphyton relationships, but they apply to chlorophyll standing crop as well as production. For example, measuring production or standing crop of the entire periphyton community can mask more subtle scraper/algae relationships. Scrapers seem to be adapted for harvesting thin organic films on substrate surfaces. Algal species which exhibit filamentous, sheet, or mat-like morphologies will not be harvested as efficiently, but will in many cases contribute significantly to total algal standing crop or primary production. In Cascade streams with open canopies, a succession of both algal species and growth forms oc- curs through the year. In shaded streams, unicellular diatoms are dominant over the entire year (Lyford and Gregory 1975). Hence, although production may be highest in open streams (Table 3), availability of species that can be harvested efficiently or digested easily (see Brown 1960, Arnold 1971) may be nearly as great or more predictable in moderately to heavily shaded streams.

Also, chlorophyll $a$ :algal biomass ratios change under different light regimes both within an algal species and with shifts in periphyton community composition (e.g., Lyford and Gregory 1975, Wetzel 1975, Perkins and Kaplan 1978). Chlorophyll $a$, therefore, can be a poor index of either periphyton biomass or production. Because the ratio of chlorophyll to biomass in periphyton is relatively low (1:60-1:200, Lyford and Gregory 1975) small differences in chlorophyll levels can represent significant differences in biomass. Chlorophyll as an index of food quality of VFPOM on the other hand is not as sensitive to such error, since possible differences in chlorophyll:algal biomass ratios are relatively insignificant when compared with the large amounts of detrital biomass mixed with chlorophyll-bearing cells. 


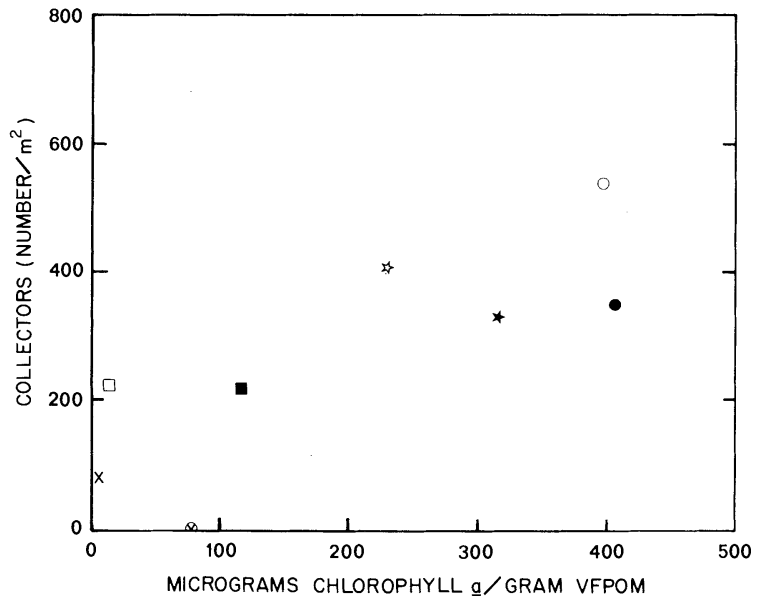

FIG. 4. Mean densities of collectors in relation to chlorophyll $a$ concentrations in VFPOM. Solid symbols $=$ summer, open symbols $=$ autumn. All symbols as in Fig. 3 except Devilsclub (DCC): $\mathrm{x}=$ summer, circled $\mathrm{x}$ (on abscissa) $=$ autumn. For all points $r=.78, P<.05, n=8$.

Presently our notions of those factors controlling scraper abuncance are useful and seem generally accurate, but more detailed investigations into periphyton/scraper interactions in stream systems are obviously needed. Nutritional constraints of food sources on scrapers have received only limited attention (e.g., McMahon et al. 1974), and studies on the effects of algal community structure on consumer abundance and vice versa in streams are practically nonexistent.

Predators. - We observed a definite positive association between densities of invertebrate predators and densities of all other invertebrates (Fig. 6) $(r=$ .55 and $.65, P<.01, n=28$ and 34 , summer and autumn, respectively). Even better correlations could have been expected for at least two reasons. Not all functional groups or individual taxa are equally susceptible to invertebrate predation. Large, and at times abundant, cased shredders or scrapers may be difficult or impossible for small predators to handle efficiently. Many invertebrate predators are known to be size selective when feeding (e.g., Sheldon 1969) and usually forage on invertebrates smaller than themselves. Our sampling and analysis excluded many smaller individuals (those passed through a $0.5-\mathrm{mm}$ sieve and all Chironomidae) that are prey to larger predators. In addition, invertebrate predators are only a part of the predator fauna found in streams. Sculpins (Cottus spp.) and salamanders (Dicamptodon ensatus) are important benthic predators in western Cascade Range streams, but were not included in this study.

Other groups.-Generalists and woodgougers were either limited in abundance or distribution. Their greatest impact was localized and at times seasonal. The section of Devilsclub Creek sampled has massive and stable accumulations of woody debris. Only here

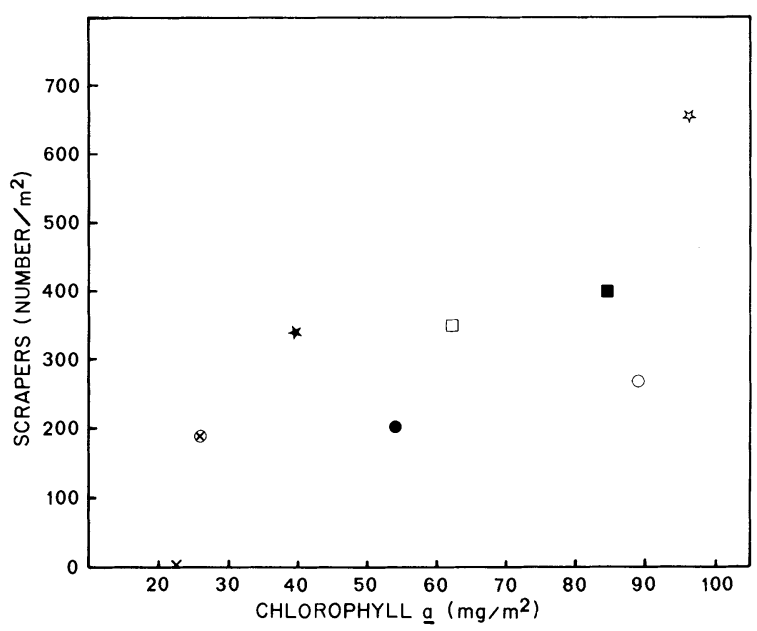

FIG. 5. Mean densities of scrapers in relation to chlorophyll $a$ standing crops on benthic rocks. Symbols as in Fig. 4. For all points $r=.76, P<.05, n=8$.

did we find an important woodgouger fauna (8-25\% of total numbers). In other streams, large pieces of wood were commonly encountered, but few woodgougers were collected by our sampling techniques. Juga plicifera, the only generalist encountered, was restricted to Lookout Creek and the McKenzie River. It was abundant in collections only during the spring and summer (4-12\%). In some Coast Range streams it is found all year and has been observed to rasp leaf surfaces actively. In Cascade streams it may be excluded by low temperatures or high gradient from many smaller streams with large leaf inputs. In our study sites, it is dormant during winter but actively scrapes periphyton and skims organic silt from stream margins and pools during warmer months.

Filter-feeders also were of only minor importance in the study streams $(0-15 \%)$. Their limited abundance is probably due to low concentrations of seston in these streams as compared with those in other biomes (Sedell et al. 1978). The scarcity of filter-feeders precluded correlations with food in transport at each site.

\section{Food resource levels and consumer abundance}

Warren (1971:261) suggests that in systems of very similar capacity to produce food, largest consumer biomass is associated with lowest food standing crops, i.e., resource depression occurs. If correct, a scatter diagram of consumer abundance vs. food would show a negative slope. Cross-comparison of systems with increasing capacities for production, however, should exhibit a positive relationship between consumers and food sources. Therefore, unless systems of markedly different capacities to produce food were examined, relationships derived from static parameters, e.g., densities and detritus standing crop, may be ambiguous.

The type of relationships between consumers and 
TABLE 3. Net daily metabolism, gross primary production, and chlorophyll $a$ standing crop associated with benthic cobbles. Abbreviations as in Table 2. Data from Naiman and Sedell 1980a.

\begin{tabular}{lcccc}
\hline \hline & DCC & MACK & LOKC & MZER \\
\hline \multicolumn{5}{c}{ Net daily } \\
Winter & 0.018 & -0.152 & 0.036 & 0.242 \\
Spring & 0.072 & 0.090 & 0.288 & 0.080 \\
Summer & -0.064 & 0.164 & 0.170 & 0.130 \\
Autumn & -0.102 & -0.044 & 0.048 & 0.276 \\
& Gross primary & production $\left(\mathrm{g} \mathrm{O}_{2} \cdot \mathrm{m}^{-2} \cdot \mathrm{d}^{-1}\right)$ \\
Winter & 0.044 & 0.182 & 0.312 & 0.660 \\
Spring & 0.198 & 0.332 & 0.782 & 0.348 \\
Summer & 0.176 & 0.598 & 0.704 & 0.740 \\
Autumn & 0.106 & 0.198 & 0.610 & 0.914 \\
& \multicolumn{4}{c}{ Chlorophyll $a\left(\mathrm{mg} / \mathrm{m}^{2}\right)$} \\
Winter & 12.3 & 36.0 & 18.3 & 58.1 \\
Spring & 18.0 & 49.5 & 59.7 & 31.1 \\
Summer & 22.7 & 84.3 & 39.7 & 53.8 \\
Autumn & 26.1 & 61.9 & 96.0 & 89.1 \\
\hline
\end{tabular}

food discussed by Warren implicitly assumes qualitative similarity between food items for each system compared. However, our discussion so far has indicated quality within some food classes in streams (CPOM, FPOM) may vary markedly. For that resource in which nutritional differences between sites may be minimal (periphyton), we have too few sampling points to examine possible relationships adequately (i.e., scraper abundance and either algal production or standing crop), although our data indicate that a direct relationship exists between food and consumer abundance (Fig. 5). Even here we have mentioned that digestibility as well as ingestibility vary widely among different species of algae. Spatial and temporal shifts in algal community composition could therefore affect the capacity of streams to support scraper populations. However, conclusions such as those drawn by Pennak (1977), that there exists no quantitative relationship between periphyton (i.e., aufwuchs or lithophyton) and bottom fauna, seem unreasonable considering the pattern of scraper abundance observed.

Populations which depend on detritus food supplies may also deviate from Warren's model because only a small part of total standing crop of detritus is actually usuable to consumers. For some detritus, quantity or standing crop of particles may actually approximate a stream segment's capacity to provide usable food. This will be true especially if detritus particles can be largely processed within the average life-span of a detritivore. Leaf and conifer needle CPOM fall into this category. CPOM provided some of the most consistent and significant correlations between animals and detritus food sources. These results agree in large part with relationships Egglishaw (1968) and Fahy (1975) observed between invertebrate density and detritus level. The presence of CPOM of other than leaf origin

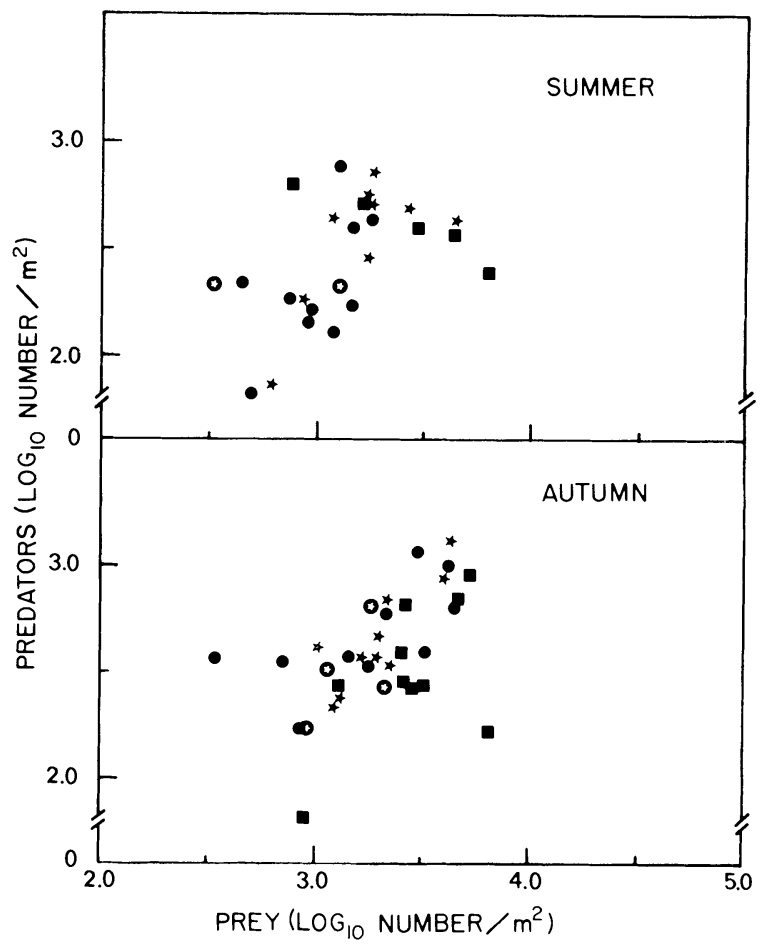

FIG. 6. Correlations of predator densities against densities of all other invertebrates (prey) for summer and autumn. Symbols as in Fig. 3. Summer: $r=.55, P<.01, n=28$; autumn: $r=.65, P<.01, n=34$.

may obscure relationships, however, as discussed earlier.

FPOM and VFPOM are similar to CPOM in that detrital pools consist of particles of different quality. Algal cells and bacteria on one hand may be extremely nutritious, whereas refractory particles generated from wood, leaf petioles and veins, and flocculated organics may act mostly as microbial substrates (Boling et al. 1975) and have little inherent nutritional value. The quality of different types of fine organics has not been investigated extensively. However, data that are available (Ward and Cummins 1979) suggest that a distinct gradient does exist. If algal-generated fines are of much higher value than allochthonous fines to consumers, it would not be surprising that quantity of FPOM and VFPOM provided minimal predictability of collector abundance. Also, algal fines must be generated from either local production or be transported from upstream reaches (Swanson and Bachmann 1976) before entering the VFPOM detritus pool. Rapid deterioration of detrital-associated chlorophyll $a$ and the lag involved between deposition of algal cells and their comsumption may tend to make chlorophyll $a$ standing crop an accurate reflection of VFPOM availability through time and thus a good predictor of collector abundance.

For the two seasons analyzed, we observed no tendency for resource depression between predators and 
their potential prey items. As noted earlier however, we did not sample either the entire predator or prey community but only invertebrates, excluding Chironomidae and vertebrates. Because large vertebrate predators feed both on invertebrate predators and nonpredators, they may act to stabilize invertebrate predator-prey ratios by consuming proportionally greater numbers of invertebrate predators than nonpredators during periods otherwise susceptible to resource depression. Because invertebrate predators are larger than most other invertebrates, they are probably selectively fed upon by vertebrate predators.

Comparison of densities should in some sense reflect the capacity of a stream section to produce individuals. We did not estimate invertebrate biomass and thus cannot evaluate whether standing crops of functional groups responded similarly to patterns of densities. However, since biomass as an index of productivity tends to underestimate production whereas densities overestimate it (see (see Odum 1971 or Whittaker 1975), estimates of biomass may not have provided any more meaningful correlations than those observed with densities. In general we should expect positive correlations between each functional group and its food source as long as consumer abundance and food availability are properly characterized.

\section{Conclusions}

In almost all nonexperimental studies, one is faced with suggesting why observed phenomena occur as they do and must usually attempt to explain why correlative data do not provide expected answers. However, if strong enough gradients are examined, realistic inferences can be made concerning those factors affecting distribution patterns (Mac Arthur 1972). The shift from headwater stream to river is such a gradient. It is a complex gradient of substrate type, current velocity, temperature regime, and food quality and quantity. In sorting out which factors are important in structuring and organizing a community, taxa should be examined from a number of perspectives.

The functional group perspective can be a useful one. In streams, temporal and spatial changes in physical environments may produce distinct shifts in species structure of communities. Functional organization may follow altogether different trends. Because the functional group classification simplifies community data, it reduces variability that is due to structural and taxonomic complexity itself. Reduction in variability enhances our ability to recognize certain trends and patterns and can thus facilitate our understanding of natural ecosystems.

We feel the usefulness of the functional group classification has been indicated. Furthermore, our data largely substantiate the River Continuum hypothesis that functional group distributions vary predictably along longitudinal profiles of stream systems that originate in woodland or forest environments.

\section{ACKNOWLEDGMENTS}

This study was supported by National Science Foundation grant BMS 75-0733. K. W. Cummins, C. E. Cushing, G. W. Minshall, R. L. Vannote, and the second author were responsible for the initial conception of the research. To them the first author extends his appreciation for the opportunity to participate in an exciting and at times exhilarating study of stream systems.

Special thanks are extended to D. A. McCullough, K. Luchessa, and R. J. Naiman of the Oregon Continuum crew and the rest of the Oregon State University Stream Team. We appreciate critical comments on early versions of the manuscript by N. H. Anderson, K. W. Cummins, S. V. Gregory, R. L. Mattingly, G. W. Minshall, R. J. Naiman, and G. M. Ward. We also thank V. Resh, his students, and an anonymous reviewer for their constructive criticisms.

The research was conducted while the authors were on the faculty in the Department of Fisheries and Wildlife, Oregon State University. We thank R. A. Tubb and J. D. Hall for their support of our research.

This paper is contribution 12 of the River Continuum Project.

\section{Literature Cited}

Anderson, N. H. 1976. Carnivory by an aquatic detritivore, Clistoronia magnifica (Trichoptera: Limnephilidae). Ecology 57:1081-1085.

Anderson, N. H., and K. W. Cummins. 1979. The influence of diet on the life histories of aquatic insects. Journal of the Fisheries Research Board of Canada 36:335-342.

Anderson, N. H., and J. R. Sedell. 1979. Detritus processing by macroinvertebrates in stream ecosystems. Annual Review of Entomology 24:351-377.

Anderson, N. H., J. R. Sedell, L. M. Roberts, and F. J. Triska. 1978. The role of aquatic invertebrates in processing of wood debris in coniferous forest streams. American Midland Naturalist 100:64-82.

Arnold, D. E. 1971. Ingestion, assimilation, survival, and reproduction by Daphnia pulex fed seven species of bluegreen algae. Limnology and Oceanography 16:906-920.

Baker, J. H., and L. A. Bradnam. 1976. The role of bacteria in the nutrition of aquatic detritivores. Oecologia 24:95104.

Barlöcher, F., and B. Kendrick. 1973. Fungi and food preferences of Gammarus pseudolimnaeus. Archiv für Hydrobiologie 72:501-516.

Bell, R. K., and F. J. Ward. 1970. Incorporation of organic carbon by Daphnia pulex. Limnology and Oceanography 15:713-726.

Boling, R. H., Jr., E. D. Goodman, J. A. Van Sickle, J. O. Zimmer, K. W. Cummins, R. C. Petersen, and S. R. Reice. 1975. Toward a model of detritus processing in a woodland stream. Ecology 56:141-151.

Bott, T. L., J. T. Brock, C. E. Cushing, S. V. Gregory, D. King, and R. C. Petersen. 1978. A comparison of methods for measuring primary productivity and community respiration in streams. Hydrobiologia 60:3-12.

Brown, D. S. 1960. The ingestion and digestion of algae by Chloeon dipterum L. Hydrobiologia 16:81-96.

Cummins, K. W. 1973. Trophic relations of aquatic insects. Annual Review of Entomology 18:183-206.

. 1974. Structure and function of stream ecosystems. BioScience 24:631-641.

- 1975. The ecology of running waters: theory and practice. Pages 277-293 in Proceedings of the Sandusky River Basin Symposium. International Joint Commission on the Great Lakes, Heidelberg College, Tiffin, Ohio, USA.

Davies, I. J. 1975. Selective feeding in some arctic Chironomidae. Verhandlungen Internationale Vereinigung für Theoretische und Angewandte Limnologie 19:3149-3154. 
Egglishaw, H. J. 1968. The quantitative relationship between bottom fauna and plant detritus in streams of different calcium concentration. Journal of Applied Ecology 5:731-740.

Fahy, E. 1975. Quantitative aspects of the distribution of invertebrates in the benthos of a small stream system in western Ireland. Freshwater Biology 5:167-182.

Gilson, W. E. 1963. Differential respirometer of simplified and improved design. Science 141:531-532.

Hargrave, B. T. 1970. The utilization of benthic microflora by Hyalella azteca (Amphipoda). Journal of Animal Ecology 39:427-437.

Hynes, H. B. N. 1970. The ecology of running waters. University of Toronto Press, Toronto, Ontario, Canada.

Iverson, T. M. 1974. Ingestion and growth in Sericostoma personatum in relation to the nitrogen content of ingested leaves. Oikos 25:278-282.

Kaushik, N. K., and H. B. N. Hynes. 1971. The fate of dead leaves that fall into streams. Archiv für Hydrobiologie 68:465-515.

Lyford, J. H., and S. V. Gregory. 1975. The dynamics and structure of periphyton communities in three Cascade Mountain streams. Verhandlungen Internationale Vereinigung für Theoretische und Angewandte Limnologie 19: $1610-1616$.

Mac Arthur, R. H. 1972. Geographical ecology: patterns in the distribution of species. Harper and Row, New York, New York, USA.

MacKay, R. J., and J. Kalff. 1973. Ecology of two related species of caddisfly larvae in the organic substrates of a woodland stream. Ecology 54:499-511.

McIntire, C. D., R. L. Garrison, H. K. Phinney, and C. E. Warren. 1964. Primary production in laboratory streams. Limnology and Oceanography 9:92-102.

McMahon, R. F., R. D. Hunter, and W. D. Russell-Hunter. 1974. Variation in aufwuchs at six freshwater habitats in terms of carbon biomass and of carbon:nitrogen ratio. Hydrobiologia 45:391-404.

Merritt, R. W., and K. W. Cummins, editors. 1978. An introduction to the aquatic insects of North America. Kendall-Hunt, Dubuque, Iowa, USA.

Naiman, R. J., and J. R. Sedell. 1979. Characterization of particulate organic matter transported by some Cascade Mountain streams. Journal of the Fisheries Research Board of Canada 36:17-31.

Naiman, R. J., and J. R. Sedell. 1980a, in press. Relationships between metabolic parameters and stream order in
Oregon. Canadian Journal of Fisheries and Aquatic Science.

Naiman, R. J., and J. R. Sedell. 1980b. Benthic organic matter as a function of stream order in Oregon. Archiv für Hydrobiologie 87:404-422.

Odum, E. P. 1971. Fundamentals of ecology. Third edition. W. B. Saunders, Philadelphia, Pennsylvania, USA.

Pennak, R. W. 1977. Trophic variables in Rocky Mountain trout streams. Archiv für Hydrobiologie 80:253-285.

Perkins, M. A., and L. A. Kaplan. 1978. Epilithic periphyton and detritus studies in a subalpine stream. Hydrobiologia 57: 103-109.

Schindler, D. W. 1968. Feeding, assimilation, and respiration rates of Daphnia magna under various environmental conditions and their relation to production estimates. Journal of Animal Ecology 37:369-385.

Sedell, J. R., R. J. Naiman, K. W. Cummins, G. W. Minshall, and R. L. Vannote. 1978. Transport of particulate organic matter in streams as a function of physical processes. Verhandlungen Internationale Vereinigung für Theoretische und Angewandte Limnologie 20:1366-1375.

Sheldon, A. L. 1969. Size relationships of Acroneuria california (Perlidae, Plecoptera) and its prey. Hydrobiologia 34:85-94.

Strahler, A. N. 1957. Quantitative analysis of watershed geomorphology. Transactions of the American Geophysics Union 38:913-920.

Strickland, J. D. H., and T. R. Parsons. 1972. A practical handbook of seawater analysis. Second edition. Bulletin of the Fisheries Research Board of Canada 167, Ottawa, Ontario, Canada.

Swanson, C. D., and R. W. Bachmann. 1976. A model of algal exports in some Iowa streams. Ecology 57:1076-1080.

Vannote, R. L., G. W. Minshall, K. W. Cummins, J. R. Sedell, and C. E. Cushing. 1980. The river continuum concept. Canadian Journal of Fisheries and Aquatic Science 37: 130-137.

Ward, G. M., and K. W. Cummins. 1979. Effects of food quality on growth of a stream detritivore, Paratendipes albimanus (Meigen) (Diptera: Chironomidae). Ecology 60:57-64.

Warren, C. E. 1971. Biology and water pollution control. W. B. Saunders, Philadelphia, Pennsylvania, USA.

Wetzel, R. G. 1975. Limnology. W. B. Saunders, Philadelphia, Pennsylvania, USA.

Whittaker, R. H. 1975. Communities and ecosystems. Second edition. MacMillan, New York, USA. 
APPENDIX

Functional feeding group classification used in this study. Some designations differ slightly from Merritt and Cummins 1978.

\begin{tabular}{|c|c|c|c|}
\hline Taxon & $\begin{array}{c}\text { Functional } \\
\text { group* }\end{array}$ & Taxon & $\begin{array}{l}\text { Functional } \\
\text { group* }\end{array}$ \\
\hline Ephemeroptera & & Limnephilidae & \\
\hline Baetidae & & Dicosmoecus sp. & $\mathrm{Sc}$ \\
\hline Baetis spp. & Co & Apatania sp. & $\mathrm{Sc}$ \\
\hline Leptophlebiidae & & Neothrema sp. & Sc \\
\hline Paraleptophlebia spp. & Co & Neophylax sp. & $\mathrm{Sc}$ \\
\hline Siphlonuridae & & Poedomoecus sierra & $\mathrm{Sc}$ \\
\hline Ameletus spp. & $\mathrm{Co}$ & Goera archaon & Sc \\
\hline Tricorythidae & & Ecclisomyia sp. & Sh \\
\hline Tricorythodes sp. & $\mathrm{Co}$ & Calamoceratidae & \\
\hline Ephemerellidae & & Heteroplectron californicum & WG \\
\hline Ephemerella doddsi & $\mathrm{Sc}$ & Coleoptera & \\
\hline Ephemerella spp. & $\mathrm{Co}$ & Dytiscidae & \\
\hline Heptageniidae & & Oreodytes sp. & $\mathrm{P}$ \\
\hline Epeorus spp. & $\mathrm{CoSc} \dagger$ & Hydrophilidae & \\
\hline Rhithrogena spp. & $\mathrm{CoSc}$ & Crenitis sp. & $\mathrm{P}$ \\
\hline Cinygma spp. & $\mathrm{CoSc}$ & Elmidae & \\
\hline Cinygmula spp. & $\mathrm{CoSc}$ & Ampumixis sp. & Co \\
\hline Plecoptera & & Cleptilmis sp. & Co \\
\hline Perlidae & & Heterlimnius sp. & Co \\
\hline Calineuria californica & $\mathrm{P}$ & Lara avara & WG \\
\hline Doroneuria theodora & $\mathrm{P}$ & Narpus sp. & Co \\
\hline Hesperoperla pacifica & $\mathrm{P}$ & Ordobrevia sp. & Co \\
\hline Chloroperlidae & $\mathrm{P}$ & Optioservus sp. & $\mathrm{Co}$ \\
\hline Perlodidae & $\mathrm{P}$ & Zeitzevia sp. & Co \\
\hline Nemouridae & Sh & Diptera & \\
\hline Leuctridae & $\mathrm{Sh}$ & Deuterophlebiidae & $\mathrm{Sc}$ \\
\hline Capniidae & $\mathrm{Sh}$ & Psychodidae & \\
\hline Peltoperlidae & & Maruina & Sc \\
\hline Peltoperla spp. & Sh & Pericoma & $\mathrm{Co}$ \\
\hline Pteronarcidae & & Ceratopogonidae & $\mathrm{P}$ \\
\hline Pteronarcys sp. & $\mathrm{Sh}$ & Simuliidae & $\mathrm{F}$ \\
\hline Trichoptera & & Tabanidae & $\mathrm{P}$ \\
\hline Philopotamidae & $\mathrm{F}$ & Tipulidae & \\
\hline Psychomyiidae & $\mathrm{C}$ & Hexatoma sp. & $\mathbf{P}$ \\
\hline Polycentropidae & & Antocha sp. & $\mathrm{P}$ \\
\hline Polycentropus sp. & $\mathrm{P}$ & Dicranota sp. & $\mathrm{P}$ \\
\hline Hydropsychidae & & Pedicia sp. & $\mathrm{P}$ \\
\hline Hydropsyche spp. & $\mathrm{F}$ & Eriopterini type & Co \\
\hline Arctopsyche grandis & $\mathrm{P}$ & Empididae & $\mathrm{P}$ \\
\hline Parapsyche sp. & $\mathrm{P}$ & Megaloptera & \\
\hline Rhyacophilidae & & Corydalidae & \\
\hline Rhyacophila spp. & $\mathrm{P}$ & Dysmicohermes sp. & $\mathrm{P}$ \\
\hline Glossosomatidae & & Sialidae & \\
\hline Glosssosoma spp. & Sc & Sialis sp. & $\mathrm{P}$ \\
\hline Agapetus sp. & Sc & Pelecypoda & \\
\hline Anagapetus sp. & $\mathrm{Sc}$ & Unknown clam & $\mathrm{F}$ \\
\hline Hydroptilidae & $\mathrm{CoSc}$ & Gastropoda & \\
\hline Brachycentridae & & Juga plicifera & $\mathrm{G}$ \\
\hline Brachycentrus sp. & $\mathrm{F}$ & Decapoda & \\
\hline Micrasema sp. & $\mathrm{Sh}$ & Pacifasticus leniusculus & $\mathrm{G}$ \\
\hline Amiocentrus sp. & $\mathrm{Sh}$ & Hydracarina & $\mathrm{P}$ \\
\hline Lepidostomatidae & & Copepoda & Co \\
\hline Lepidostoma spp. & Sh & Oligochaeta & Co \\
\hline * Collectors & $\mathrm{Co}$ & & \\
\hline Scrapers & $\mathrm{Sc}$ & & \\
\hline Collector/Scraper & $\mathrm{CoSc}$ & & \\
\hline Shredder & $\mathrm{Sh}$ & & \\
\hline Filterer & $\mathrm{F}$ & & \\
\hline Predator & $\mathrm{P}$ & & \\
\hline Woodgouger & WG & & \\
\hline Generalist & $\mathrm{G}$ & & \\
\hline
\end{tabular}

